\title{
STAVEBNÉ A MATERIÁLOVÉ MOŽNOSTI ZNIŽOVANIA HLUKU V ŽELEZNIČNEJ DOPRAVE
}

\author{
STRUCTURE AND MATERIAL POSSIBILITIES OF RAILWAY TRAFFIC NOISE \\ REDUCTION
}

Ing. Pultznerová Alžbeta, Ph.D.; Ing. BavIna Lukáš; prof.Ing. Zvolenský Peter, Ph.D.

\begin{abstract}
ABSTRAKT
Príspevok uvádza príklady a možnosti stavebných úprav ako na železničnej trati tak aj na železničnom vozidle, ktoré znižujú hluk. Ďalej sa zaoberá materiálovými možnost’ami a to hlavne novým materiálom STERED z pohl'adu protihlukových vlastností. Porovnáva ho s akustickými vlastnost'ami minerálnej vlny pomocou 2D počítačovej simulácie. V príspevku sú uvádzané možnosti použitia tohto materiálu ako pri odhlučnení železničného vozidla, tak aj na vonkajšie použitie v stavbe železničnej trate.
\end{abstract}

Kl'účové slova: železničná trat', železničné vozidlo, protihlukové opatrenia, materiál STERED

\section{ABSTRACT}

The paper deals with examples and possibilities for building modifications both the railway track as well as the rail vehicle, which reduces noise. Furthermore it deals with material characteristics and especially a new material STERED from the noise reduction point of view. It is compared with the acoustic properties of mineral wool using 2D computer simulation. Possibilities of using this material for noise elimination of railway vehicles as well as for outdoor use in the structure of the railway line are mentioned in the paper.

Key words: railway track, railway vehicle, noise reducing arrangements, material STERED

\section{1 ÚVOD}

Neustále vzrastajúca intenzita dopravy a súčasne zvyšujúca sa senzibilita obyvatel'stva voči zat'aženiu hlukom núti vlastníkov a prevádzkovatel'ov dopravnej cesty realizovat' účinné opatrenia na znižovanie hlukových imisií ako pre lepší komfort dopravy cestujúcich vo vozidle tak pre zníženie negatívnych dopadov z dopravy na jej okolie. Hluk, ktorý vzniká od pohybujúcej sa vlakovej súpravy na kontakte koleso/kol'ajnica je dominujúcim a rozhodujúcim zdrojom hluku z kol'ajovej dopravy, ktorý sa šíri jednak v konštrukcií vozňa a jednak je vyžarovaný do okolia.

Na šírenie hluku vo vozidle a jeho vyžarovanie do interiéru má rozhodujúci vplyv jeho konštrukčné riešenie a materiálové vyhotovenie. $\mathrm{Na}$ emisiu hluku od zdroja jeho vzniku do jeho okolia má rozhodujúci vplyv topografia terénu a prekážky na trase, ktorými sú napr. aj hlukové bariéry.

\section{PROTIHLUKOVÉ OPATRENIA}

Protihlukové opatrenia v železničnej doprave môžu byt' aktívne a pasívne. Aktívne protihlukové opatrenia sú také konštrukčné úpravy na železničných vozidlách a na železničných tratiach, ktorými sa zníži generovaný hluk emitovaný do prostredia. Pasívne protihlukové opatrenia sú opatrenia, ktorými sa tlmí už vzniknutý hluk na dráhe šírenia zvuku k prijímatel’ovi alebo do priestoru všeobecne. 


\subsection{Aktívne protihlukové opatrenia na železničnej trati}

Medzi aktívne protihlukové opatrenia na železničnej trati patrí hlavne: pravidelná údržba železničného zvršku, aplikácia moderných konštrukcií železničného zvršku a typov výhybiek, kvalitná konštrukcia kolajnice, vhodná konštrukcia mostných objektov, použitie antivibračných rohoží a podložiek do konštrukcie železničného zvršku a v posledných rokoch aj kol’ajnicové absorbéry prichytené $\mathrm{k}$ stojine kol'ajnice.

Kol’ajnicový absorbér má vd’aka svojmu konštrukčnému zloženiu vysoké absorbčné vlastnosti (obr. 1), ktorými absorbuje vznikajúce vibrácie na rozhraní koleso/kolajnica a zabraňuje tým generovaniu hluku v kol'ajnici a taktiež spôsobuje rýchlejší jej útlm. V prípade prechodu vlaku sa v styku medzi kolesom a kolajnicou generuje hluk rôzneho frekvenčného spektra. Kol'ajnicový absorbér funguje na systéme absorpcie vibrácii na frekvenciách s najväššími hladinami hluku. [1].

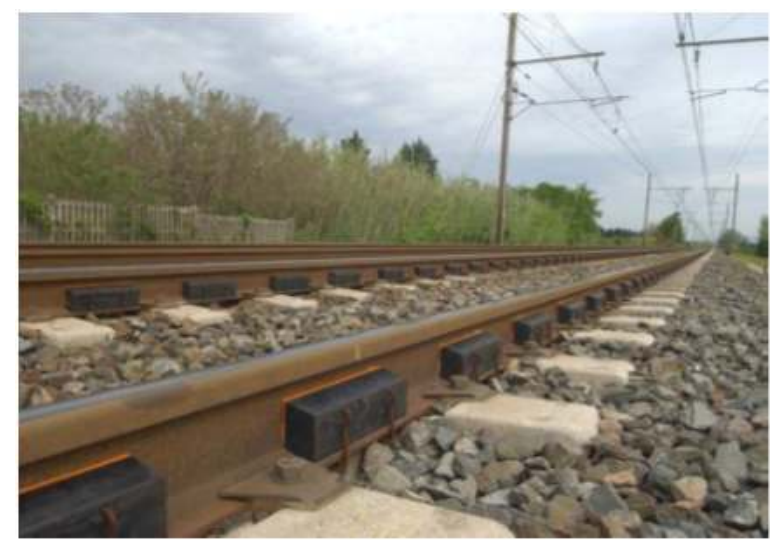

Obr. 1 Kol’ajnicový absorbér firmy Vossloh [1]

Kolajnicové absorbéry znižujú hluk všeobecne o 1-3dB, pri dobrom navrhnutí $4-7 \mathrm{~dB}$ [1]. Hlavnou ich výhodou je, že je ich možné namontovat' aj po zriadení úseku v kritických miestach pre zlepšenie hlukových parametrov po uvedení stavby do prevádzky, nedochádza k obmedzeniam pri údržbe trati, bezúdržbovost' kol'ajnicového absorbéra a nezasahuje do celkového vzhl'adu trate.

\subsection{Aktívne protihlukové opatrenia na železničnom vozidle}

$\mathrm{Na}$ železničných vozidlách, či už hnacích alebo hnaných, je možné znižit' hlukové emisie konštrukčnými opatreniami na rôznych zariadeniach a konštrukčných prvkoch na hnacom vozidle, železničnom vagóne, vhodným typom a materiálom bŕzd, optimalizáciou tvaru kolesa a použitím kolesového protihlukového absorbéra. Pri vyšších rýchlostiach aerodynamickým tvarom skrine a vhodným tvarom zberačov. Pravidelnou kontrolou a údržbou kolies, podvozku a celkového stavu vozidla.

Použitie kolesového protihlukového absorbéru znižuje nielen množstvo emitovaného hluku, ale ho aj pretransformuje do vyššieho frekvenčného pásma a redukuje hladinu hluku v porovnaní s tradičným kolesom. Použitím kolesového protihlukového absorbéru je možné dosiahnut zníženie hluku na priamom úseku trati o $1 \mathrm{~dB}$, v prípade oblúku malého polomeru, kde pri prejazde štandardného kolesa vzniká škrípavý zvuk, až o 5-15 dB [3].

\subsection{Pasívne protihlukové opatrenia}

Pasívne protihlukové opatrenia sú realizované hlavne priamo na konštrukcii železničnej trate. Na železničnom vozidle sú to len tieniace kryty na vozňovej skrini. 
Protihlukové opatrenia, ktoré sú súčastou železničnej trate, sú: uzatvorená tunelová trasa, protihluková stena, nízka protihluková bariéra (obr. 2), malá kol’ajnicová protihluková stienka a absorpčné rohože.

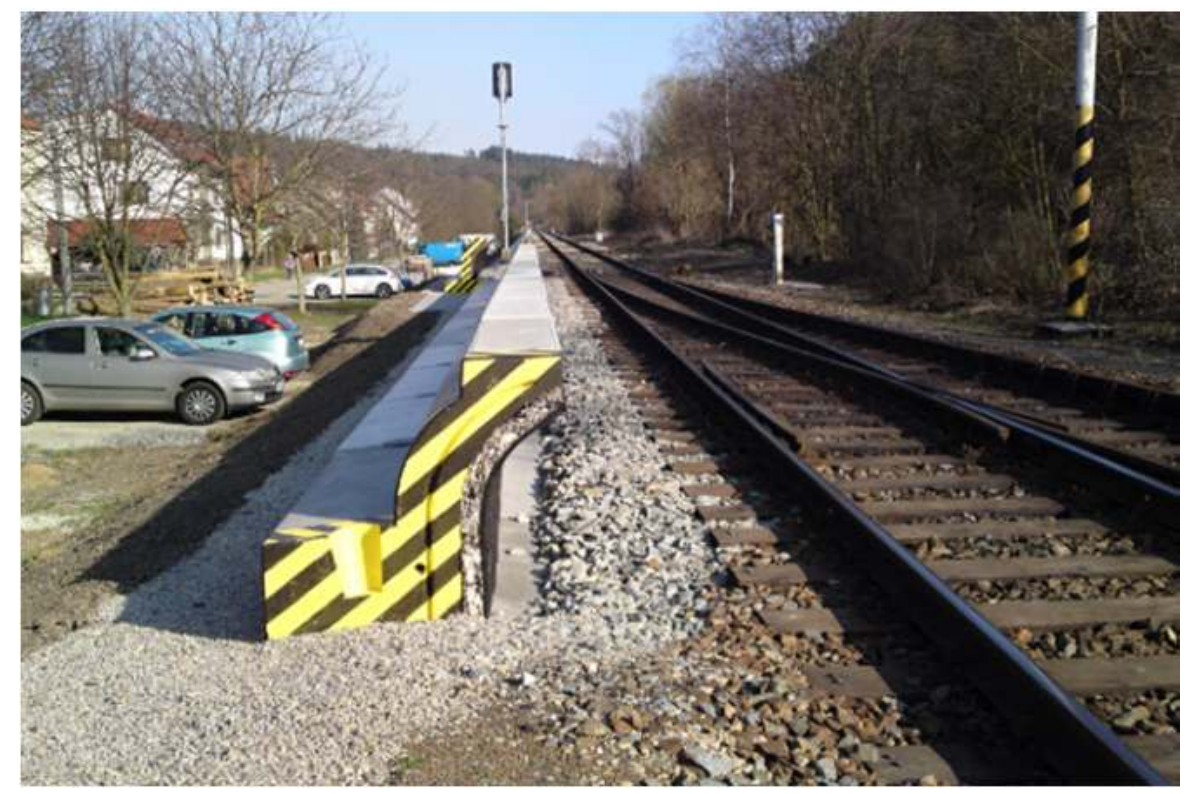

Obr. 2 Nízka protihluková barié ra [2]

\section{PROTIHLUKOVÉ MATERIÁLY}

V súčasnosti sú tvarové a konštrukčné opatrenia na takom stupni vývoja, že sú už na hranici svojich technologických a technických možností. Napríklad, čo sa týka protihlukových bariér je ich tvar tak optimalizovaný, že ich akustické vlastnosti už viac závisia na použitých materiáloch.

V súčasnosti na znižovania hluku sa použivajú rôzne porézne a vláknité absorpčné materiály. Pri prechode akustickej vlny poréznym materiálom dochádza $\mathrm{k}$ viskóznemu treniu častíc vzduchu $\mathrm{s}$ povrchom stien póru materiálu. Zvuková energia sa pritom mení na tepelnú.
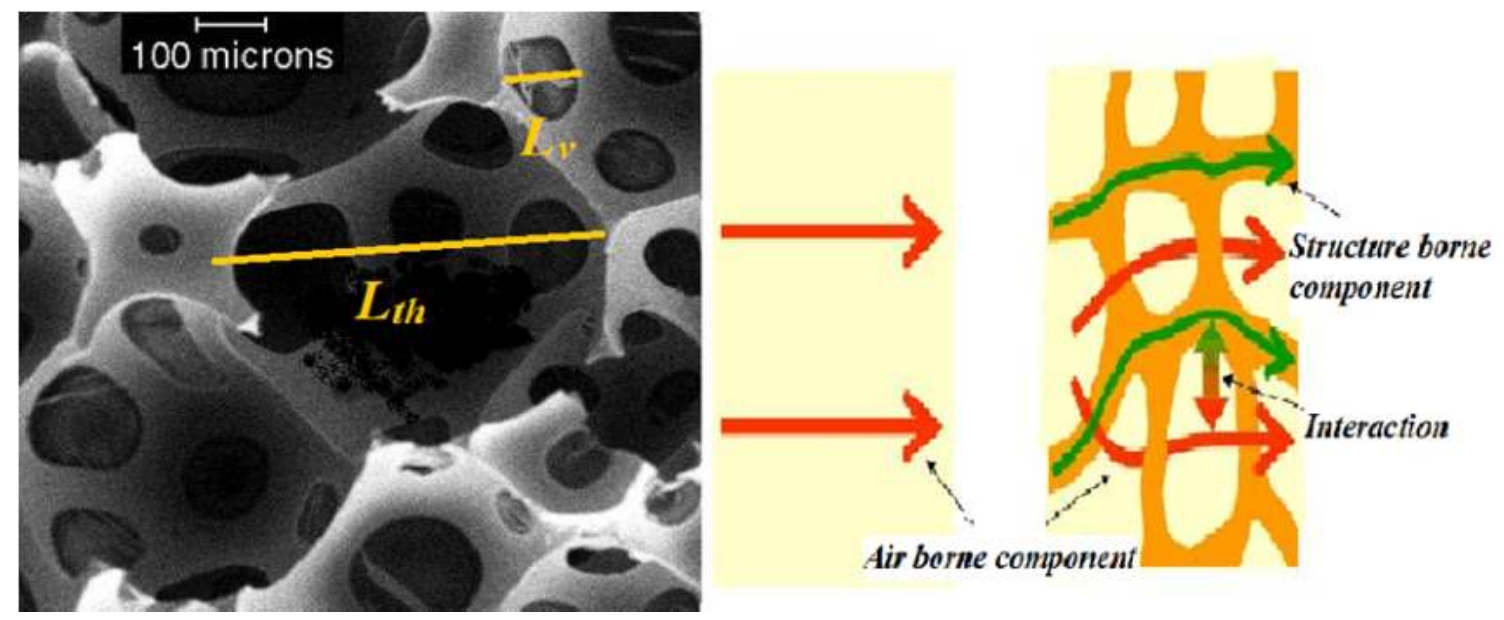

Obr. 3 Termálna a viskózna charakte ristická dížka a šírenie akustickej vlny v poréznom materiáli $[4,6]$

Najväčší vplyv na akustické vlastnosti porézneho materiálu má jeho termálna a viskózna charakteristická dížka (obr.3). Tieto charakteristiky sú skalárnou veličinou. Pre sférické póry sa bliži hodnota $\mathrm{L}_{\mathrm{th}} \mathrm{k}$ polomeru póru. Hodnota parametra $\mathrm{L}_{\mathrm{v}}$ sa blíži k hodnote polomeru kanálika, ktorý spája póry. Z 2D a 3D akvizície mikroštruktúry materiálu sa dajú tieto údaje zistit'. [4] 
V súčasnosti sa použiva pre znižovanie hluku široké spektrum poréznych materiálov. Medzi najčastejšie patrí minerálna vlna, ktorá sa využiva v mnohých konštrukciách (obr.4). Minerálna vlna má však oproti modernejším tepelným a zvukovým izolantom vel’a nevýhod. Je to zdraviu škodlivý materiál, ktorý má nízku pružnost', ktorú časom stráca. Dochádza k starnutiu a k strate objemu, pričom radikálne stráca aj tepelno-izolačné vlastnosti.
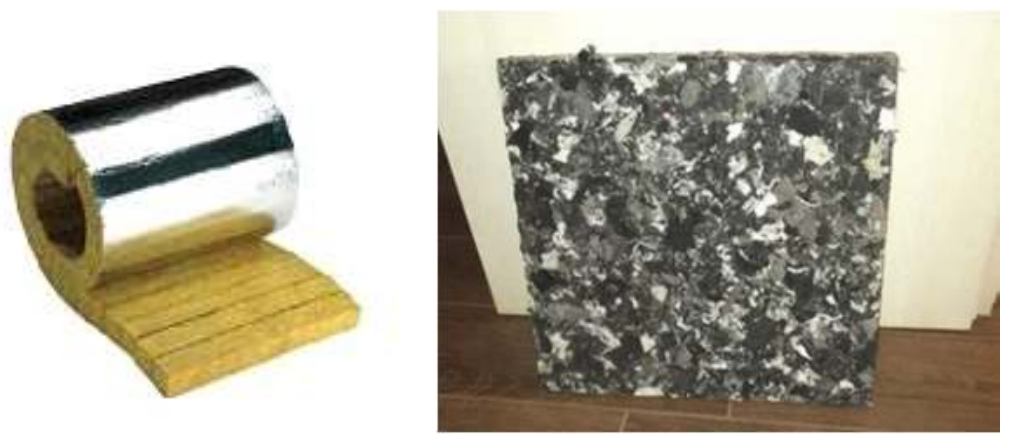

Obr. 4 Mine rálna vlna firmy Knauf insulation LMF 10 Alu R a materiál STERED® [5, 7]

Ďalším poréznym materiálom, ktorý má výborné zvukovo a tepelne izolačné vlastnosti je STERED. Vstupný materiál pozostáva z odpadu pri výrobe nových automobilov ich textilných dielov, ale aj z vozidiel po skončení životnosti z vyseparovaných textilných častí, čím vznikajú značné objemy textilných materiálov osobitných kvalít. Pre tento materiál je charakteristické:

- má vynikajúce vlastnosti, ktoré sa ani časom nemenia,

- materiál pôvodne použitý $\mathrm{v}$ automobile bol určený ku zvukovej a tepelnej izolácii, pritom musí spĺn̆at' hlavne prísne požiadavky zdravotnej nezávadnosti [5].

\section{VYUŽITIE MATERIÁLU STERED PRI ZNIŽOVANÍ HLUKU V ŽELEZNIČNEJ DOPRAVE}

Materiál môže mat' široké uplatnenie $\mathrm{v}$ žel. doprave ako $\mathrm{v}$ konštrukcií vozidla, tak pri pasívnych protihlukových opatreniach - povrchová úprava protihlukových stien. V konštrukciách dopravných prostriedkov môže byt' použitá aj ako tepelne akustická izolácia podlahy a stien vozña.

\subsection{D počítačová simulácia}

Pre zistenie akustických parametrov materiálu STERED bola využitá na Žilinskej univerzite počítačová simulácia. Pre simuláciu prestupu akustického tlaku cez konštrukciu podlahy osobného vozn̆a radu Bdghmeer bol zvolený, ako vhodný nástroj program COMSOL Multiphysics 4.4. Ciel’om simulácie bolo vykonat' frekvenčnú analýzu a zistit' prípadné rozdiely medzi materiálmi minerálna vlna a STERED v útlme daného frekvenčného spektra.

Na povrch trapézového plechu pôsobil akustický tlak o hodnote $20 \mathrm{~Pa}(120 \mathrm{~dB})$. Tento tlak pôsobil vo frekvenčnom spektre $5 \mathrm{~Hz}$ až $20 \mathrm{kHz}$. Počas simulácie bolo možné sledovat' prestup tohto tlaku celou konštrukciou podlahy až do interiéru vozidla $v$ tomto frekvenčnom spektre. Útlm je možné zistit' porovnaním frekvenčných analýz nameraných $\mathrm{v}$ jednotlivých vrstvách konštrukcie podlahy a interiéru vozňa. Vyhodnotenie je pomocou funkcie Pointgraph, kde je možné v spomínaných bodoch obr. 6 zaznamenat' hodnoty akustického tlaku v závislosti od frekvencie budenia. 


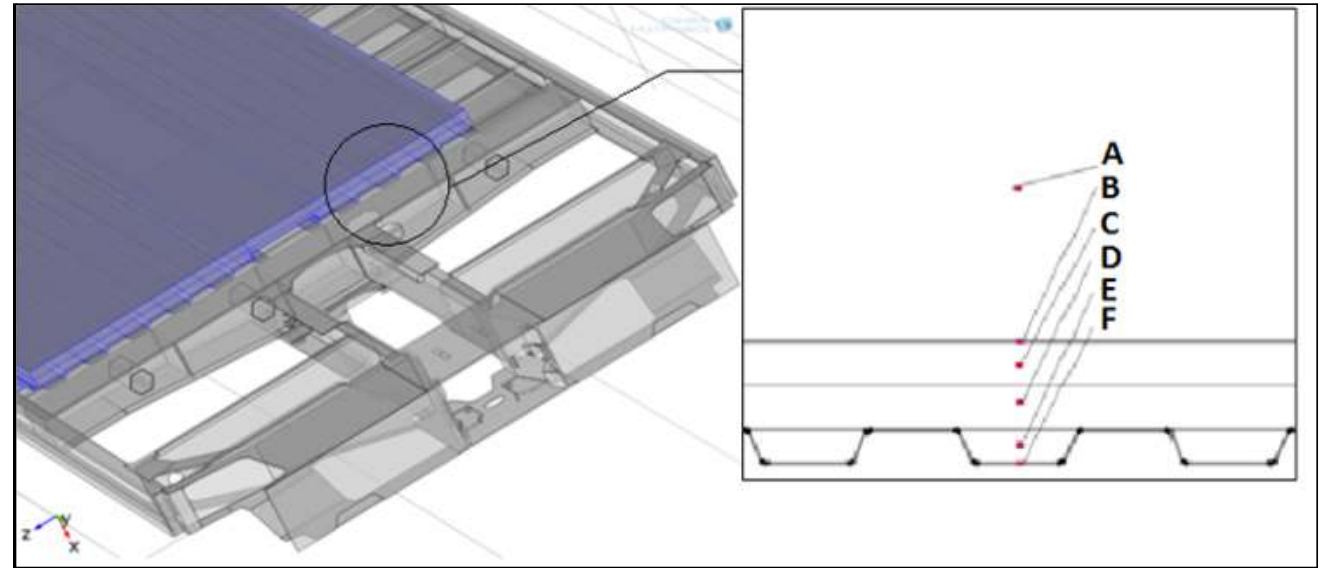

Obr. 6 Meracie body v o vrstvách konštrukcie podlahy. A- vnútrajšok vozidla, B - PVC, C - preglejka, D - STERED®/Mine rálna vlna, E - vzduchová medzera, F - Trapézový plech (autor)

Použitím programu COMSOL Multiphysics boli simulované prvotné podmienky prechodu hluku od pojazdu železničného osobného vožna cez jeho podlahu (Tab.1).

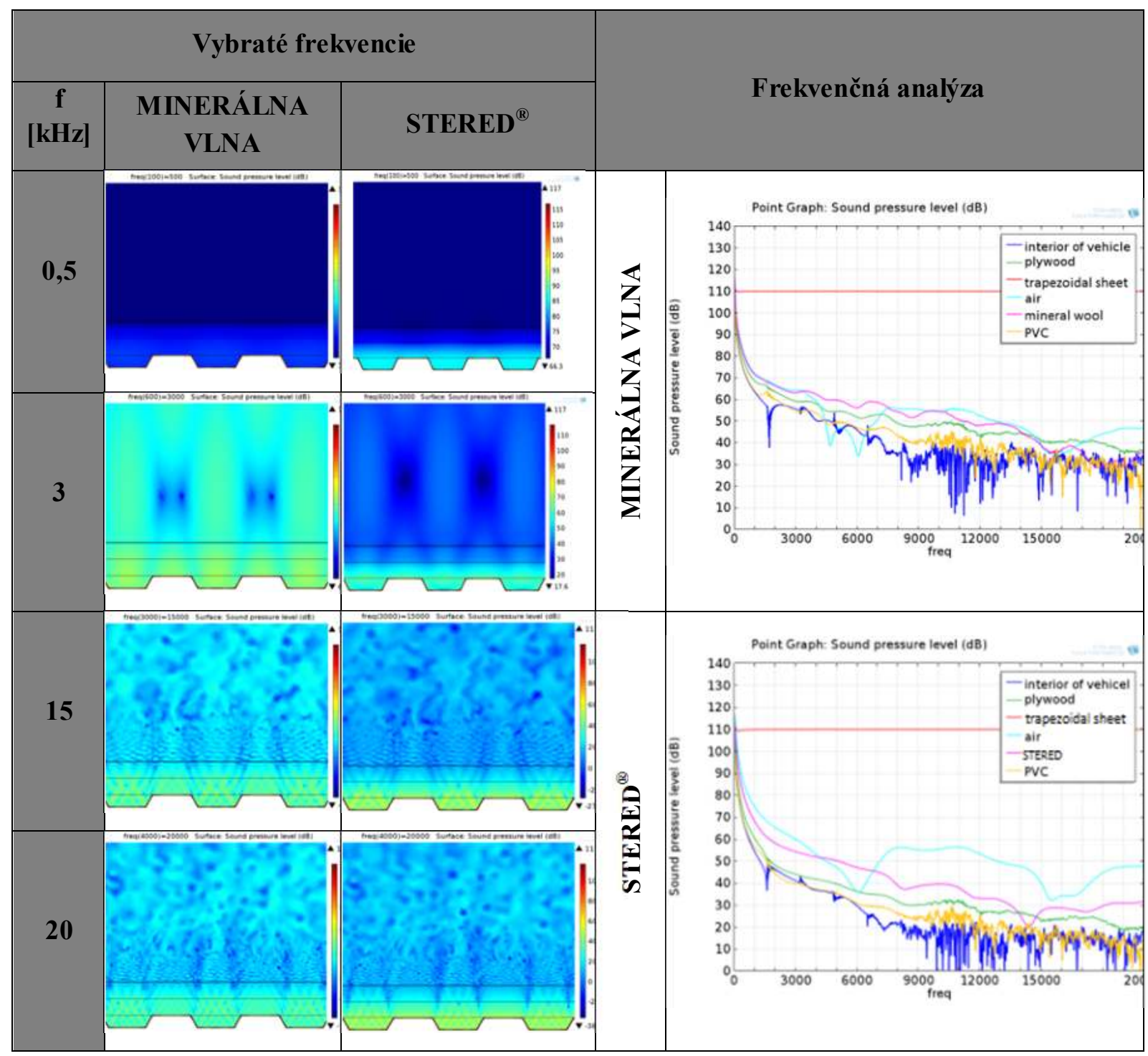

Tab. 1 Výsledok simulácie prechodu akustického tlaku cez konštrukciu steny vozňa (autor) 


\section{2 Ďalšie možné využitie materiálu STERED v stavebných konštrukciách železničnej trate}

Ďalšie využitie materiálu STERED sa dá uplatnit' v konštrukcií kol'ajnicových absorbérov, pri nízkych protihlukových stenách a pri konštrukcií kol’ajového lôžka ako antivibračné podložky (obr.7).

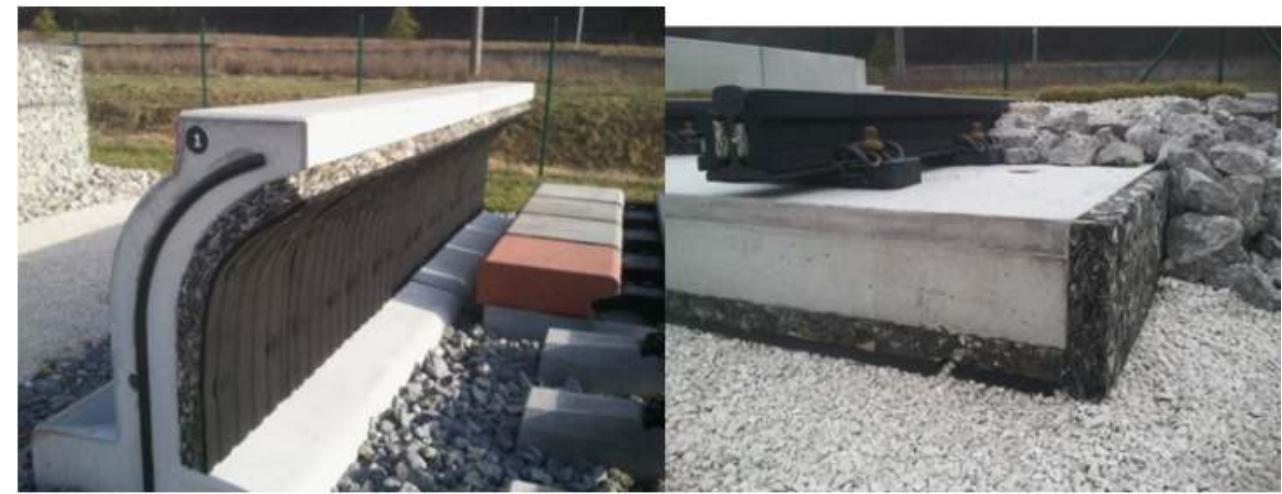

Obr. 7 Možnosti použitia materiálu STERED v konštrukcií kol’ajového lôžka [5]

\section{ZÁVER}

Z výsledkov simulácie je zrejmé, že materiál STERED vykazuje lepšie akustické výsledky ako materiál minerálna vlna približne o $10-15 \mathrm{~dB}$, najmä v oblasti vyšších frekvencií.

Materiál STERED je získavaný recykláciou textilného odpadu, ktorý bol tepelným a akustickým izolantom v automobilovom priemysle. Základný materiál tvoria syntetické vlákna, ktoré majú vysokú odolnost' aj voči poveternostným vplyvom. Tým pádom môže byt' využitý aj v exteriéri a má široké uplatnenie.

Pod'akovanie

Práca je podporovaná z prostriedkov grantového projektu VEGA 1/0766/15 Výskum zdrojov hlukových emisií v železničnej doprave a spôsoby ich efektívneho znižovania.

\section{Použitá literatúra}

[1] Benton, David: Railway noise in urban areas: possible source noise reduction measures. Pisa 9-10 November 2006, European Workshop

[2] Eisenreich, Jan: Nízké protihlukové clony pro železniční a tramvajové tratě, WebArchiv, Časopis Stavebnictví, 9/14, 2014, Načítané z http://www.casopisstavebnictvi.cz/nizkeprotihlukove-clony-pro-zeleznicni-a-tramvajove-trate_N5330\#, cit.18.11.2015

[3] Ho, Wilson: RAIL DAMPER LATEST DEVELOPMENT, REDUCTION OF NOISE RADIATION AND CORRUGATION GROWTH, 20th aniversary of Hon Kong Instituce of Acoustics

[4] Jaouen, L. Načítané z http://apmr.matelys.com/Parameters/Characterization/Acoustics/ ThermalCharacteristicLength.html cit. 8. 12015.

[5] Stered v dopravnej infraštruktúre, Načitané z http://www.stered.sk/stered-v-dopravnejinfrastrukture, cit. 18.11.2015

[6] Wison technology, Expertise in Power Solution (2015). http://wisonpower.com/. Cit. 24. 2. 2015, z http://wisonpower.com/sub/product_view.php?idx=94\&cat_no=

[7] http://www.knaufinsulation.sk/lmf-10-alur-40-mm, cit 18.11.2015 